\title{
ANALISIS KEMAMPUAN KOMUNIKASI MATEMATIS SISWA SMP MELALUI SELF CONFIDENT PADA MATERI RELASI DAN FUNGSI
}

\author{
Rismayantini $^{1}$, Siti Nurajizah ${ }^{2}$ \\ 1,2 IKIP Siliwangi, Jalan Terusan Jenderal Sudirman, Cimahi, Jawa Barat, Indonesia \\ rismayantini21@gmail.com
}

\begin{abstract}
This research is motivated by the importance of social arithmetic material in mathematics especially for students as educational subjects in daily life, while the aim is to analyze students'difficulties in solving social arithmetic questions in the form of contextual questions. This study is classified as a qualitative descriptive study that illustrates the ability of students to solve social arithmetic problems in which the question is based cognitive bloom. The population in this study were all eighth grade junior high school students in West Bandung regency whose samples were selected randomly in Mahardika Middle School as many as 31 people. The data was obtained by testing 8 test question containing the cognitive bloom domain with $3 \mathrm{C} 3$ details, $3 \mathrm{C} 4$ questions and 2 C5 questions. The results showed that there were 1 people with high ability, 2 people with moderate abilities, and 28 people with low abilities with various errors including misconceptions, principle errors, and data operation errors, while the average acquisition rate was $25,7 \%$. It can be concluded that the ability of students to solve problems is still relatively low so that efforts are needed to improve abilities.
\end{abstract}

Keywords: Social Arthmetic

\begin{abstract}
Abstrak
Penelitian ini dilatarbelakangi oleh pentingnya materi aritmatika sosial di dalam pelajaran matematika terutama bagi siswa sebagai subjek pendidikan di dalam kehidupan sehari-hari, sedangkan tujuannya adalah untuk menganalisis kesulitan siswa dalam menyelesaikan soal aritmatika sosial yang berbentuk soal kontekstual. Penelitian ini tergolong penelitian deskriptif kualitatif yang menggambarkan kemampuan siswa dalam menyelesaikan soal aritmatika sosial yang mana soal tersebut pembuatannya didasarkan pada ranah kognitif bloom. Populasi dalam penelitian ini adalah seluruh siswa SMP kelas VIII di kabupaten Bandung Barat yang sampelnya dipilih secara acak di SMP Mahardika sebanyak 31 orang. Data diperoleh dengan mengujikan soal tes sebanyak 8 soal yang memuat ranah kognitif bloom dengan rincian C3 sebanyak 3 soal, C4 sebanyak 3 soal dan C5 sebanyak 2 soal. Hasil penelitian menunjukkan terdapat 1 orang yang berkemampuan tinggi, 2 orang yang berkemampuan sedang, dan 28 orang berkemampuan rendah dengan kesalahan yang bervariasi diantaranya kesalahan konsep, kesalahan prinsip, dan kesalahan pengoperasian data, sedangkan rata-rata perolehan kelas sebesar $25,7 \%$. Dapat diambil kesimpulan bahwa kemampuan siswa dalam menyelesaikan soal masih tergolong rendah sehingga diperlukan upaya peningkatan kemampuan.
\end{abstract}

Kata kunci: Aritmatika Sosial

\section{PENDAHULUAN}

Matematika merupakan ilmu pengetahuan yang dapat dijadikan bekal bagi manusia untuk menguasai pengetahuan dan teknologi. Hal tersebut sejalan dengan pernyataan Suherman (2003) yang menyatakan bahwa matematika merupakan ratunya ilmu dan pelayan ilmu, artinya matematika dapat berdiri sendiri bahkan dijadikan sebagai pusat pengembangan ilmu lain. Matematika juga berperan penting dalam tujuan pendidikan nasional yaitu mencerdaskan generasi bangsa dan membentuk karakter bangsa sesuai kepribadian manusia Indonesia (Fitiani, 2015). Nurfauziah \& Fitriani (2019) menyatakan bahwa pentingnya matematika adalah melatih peserta didik untuk berpikir matematis diantaranya logis dan kritis serta analitis agar siswa mampu dan terbiasa memecahkan masalah.

Matematika memiliki sifat korelatif dimana setiap pembahasan matematika memiliki keterkaitan dengan pembahasan materi sebelumnya. Artinya siswa dituntut untuk berpikir logis dan 
terbuka dalam menerima pembelajaran. Salah satu topik pembahasan matematika yang diajarkan di tingkat SMP adalah aritmatika sosial yang merupakan aplikasi dari materi aljabar. Aritmatika sosial merupakan bab di dalam matematika yang membahas mengenai perhitungan keuangan dan perdagangan dalam kehidupan sehari-hari (Paramitha \& Yunianta, 2017). Adapun cukupan materinya meliputi harga pembelian dan penjualan, keuntungan dan kerugian, persentase untung dan rugi, diskon, dan bunga tunggal. Melihat dari pembahasan yang disampaikan, materi ini sangat penting bagi siswa sebagai untuk dijadikan sebagai bekal menjalani kehidupan di lingkungan sosial.

Matematika tidak selalu menyajikan soal abstrak yang jauh dari kehidupan siswa, namun sebenarnya matematika itu dekat dengan siswa. Permasalahan kontekstual lebih memudahkan siswa dalam menyelesaikan masalah karena adanya dasar pengetahuan yang diterima secara tidak langsung di dalam kehidupan bermasyarakat sehingga siswa dalam menyelesaikan persoalan memperhatikan sungguh-sungguh langkah penyelesaian dan hal tersebut berpengaruh terhadap kemampuan berpikir matematis (Wahyuddin, 2017). Sejalan dengan Ruseffendi (2006) yang menyatakan bahwa syarat utama bagi siswa menyesaikan soal terutama soal tidak rutin adalah adanya pengetahuan dasar.

Dasar dalam pembuatan soal untuk lebih memaksimalkan siswa dalam melatih kemampuan berpikir adalah taksonomi bloom. Ranah kognitif bloom dimulai dari C1 (mengingat), C2 (memahami), C3 (menghitung), C4 (menganalisis), C5 (membandingkan), dan C6 (mencipta). Irawati \& Mahmudah (2018) menyatakan bahwa bahwa C4-C6 merupakan soal dengan kategori High Order Thinking (HOT) sedangkan C1-C3 termasuk ke dalam kategori Low Order Thinking (LOT). Sementara, Rahmah \& Muharni (2019) menyatakan bahwa soal dengan kriteria mudah (C1-C2), kategori sedang (C3-C4), sementara kategori sulit (C5-C6). Idealnya dalam persoalan matematik jumlah perbandingan soal mudah, sedang, dan sulit adalah 3:4:3 (Giani, Zulkardi, \& Hiltrimartin, 2015).

Pentingnya penguasaan materi aritmatika sosial tidak diimbangi dengan fakta di lapangan. Studi pendahuluan yang dilakukan oleh Astutik \& Nuriyatin (2016) menyimpulkan bahwa siswa banyak melakukan kesalahan konsep sebesar 37,73\%, kesalahan prinsip sebesar 50\%, dan kesalahan teknik sebesar 31,18\% pada saat menyelesaikan soal aritmatika sosial. Penelitian yang dilakukan Sari, Susanti, \& Rahayu (2018) menganalisis kesalahan siswa dalam mengerjakan soal aritmatika sosial yaitu kesalahan dalam menulis ulang informasi yang tersedia, kesalahan dalam membuat model matematika, dan kesalahan dalam melakukan operasi bilangan bulat dan desimal.

Berdasarkan hal tersebut, peneliti melakukan penelitian untuk menganalisis kesalahan siswa SMP dalam menyelesaikan soal kontekstual pada materi aritmatika sosial. 


\section{METODE}

Penelitian ini menggunakan metode penelitian kualitatif yang hasil penelitiannya diuraikan secara deskriptif. Populasi penelitian ini adalah seluruh siswa kelas VIII di Kabupaten Bandung Barat yang sampel diambil secara acak dan terpilih kelas VIII-E SMP Mahardika Batujajar sebanyak 31 orang. Peneliti tidak memberikan perlakuan kepada sampel namun hanya memberikan instrumen tes yang nantinya akan dideskripsikan kesalahan siswa dalam menyelesaikan soal aritmatika sosial. Instrumen tes tersebut berisikan 8 soal yang disusun berdasarkan tingkatan kognitif bloom dengan rincian $\mathrm{C} 3$ sebanyak 3 soal, C4 sebanyak 3 soal, dan C5 sebanyak 2 soal.

Hasil penelitian selajutnya dilakukan proses penskoran pada tiap soal dengan berpedoman pada rubrik, sehingga diketahui jumlah skor masing-masing sampel. Selanjutnya dilakukan perhitungan rata-rata dengan tujuan untuk mengetahui persentase rata-rata kemampuan sampel.

\section{Tabel 1}

Penggolongan Kemampuan Rata-Rata Siswa

\begin{tabular}{|l|c|}
\hline \multicolumn{1}{|c|}{ Persentase } & Klasifikasi \\
\hline $0 \% \leq P<20 \%$ & Sangat rendah \\
\hline $20 \% \leq P<40 \%$ & Rendah \\
\hline $40 \% \leq P<60 \%$ & Sedang \\
\hline $60 \% \leq P<80 \%$ & Tinggi \\
\hline $80 \% \leq P<100 \%$ & Sangat tinggi \\
\hline
\end{tabular}

(Romika \& Amalia, 2014)

Pedoman skor yang digunakan sebagai berikut:

\section{Tabel 2}

\section{Pedoman Penskoran Taksonomi Bloom}

\begin{tabular}{|l|c|c|c|}
\hline \multirow{2}{*}{ Langkah Penyelesaian } & \multicolumn{3}{c|}{ Skor Perolehan } \\
\cline { 2 - 4 } & C3 & C4 & C5 \\
\hline Tidak ada jawaban & 0 & 0 & 0 \\
\hline $\begin{array}{l}\text { Memahami masalah dengan menuliskan data yang } \\
\text { diketahui menggunakan bahasa sendiri }\end{array}$ & $0-1$ & $0-2$ & $0-3$ \\
\hline Membuat rencana penyelesaian & $0-1$ & $0-2$ & $0-3$ \\
\hline Menjalankan rencana yang telah dibuat & $0-1$ & $0-2$ & $0-3$ \\
\hline $\begin{array}{l}\text { Melakukan pengecekan kembali sehingga dapat } \\
\text { menyimpulkan }\end{array}$ & $0-1$ & $0-2$ & $0-3$ \\
\hline \multicolumn{1}{|c|}{ Rentang Perolehan Skor } & $0-4$ & $0-8$ & $0-12$ \\
\hline
\end{tabular}

Pedoman penskoran tersebut digunakan oleh peneliti untuk mengelompokkan siswa menjadi tiga kategori yaitu siswa berkemampuan tinggi $(X \geq 80)$, sedang $(65<X<80)$, dan rendah (X $\leq 65)$ (Kurniawan \& Setiawan, 2019) 


\section{HASIL DAN PEMBAHASAN}

Penelitian yang telah dilakukan pada tanggal 15 Januari 2020 dengan memberikan instrumen tes yang memiliki validitas isi kepada 31 sampel, setelah dilakukan proses penskoran dengan berpedoman rubrik penskoran di Tabel 2, memberikan hasil sebagai berikut:

\section{Tabel 3}

Rekapitulasi Perolehan Skor Siswa

\begin{tabular}{|l|c|c|c|}
\hline \multicolumn{1}{|c|}{ Rentang Nilai } & Jumlah Siswa & Kategori & Persentase \\
\hline$X \geq 80$ & 1 & Tinggi & $3,22 \%$ \\
\hline $65<X<80$ & 2 & Sedang & $6,46 \%$ \\
\hline$X \leq 65$ & 28 & Rendah & $90,32 \%$ \\
\hline \multicolumn{2}{|c|}{ Persentase Rata-Rata Kemampuan } & $25,7 \%$ \\
\hline
\end{tabular}

Tabel 3 merupakan hasil nilai siswa terhadap pengerjaan soal aritmatika sosial dan diperoleh 1 orang siswa dengan kategori tinggi, 2 orang siswa dengan kategori sedang, dan 28 orang dengan kategori rendah dengan rata-rata persentase kemampuan sebesar 25,7\%. Berdasarkan tabel 1 persentase rata-rata kemampuan siswa berada pada kategori rendah. Artinya siswa masih mengalami kesulitan dalam melakukan pengerjaan soal yang diujikan, dan diperkuat dengan masih mendominasinya siswa dengan kemampuan rendah yaitu sebesar 90,32\%, sementara siswa yang berada pada kategori sedang hanya sebesar $6,46 \%$ dan siswa yang berada pada kategori tinggi hanya 3,22\%. Kesulitan-kesulitan siswa tersebut akan dianalisis pengerjaannya.

Soal yang akan digunakan untuk menganalisis kesalahan siswa merupakan soal dengan ranah kognitif bloom C5. Adapun bentuk soalnya sebagai berikut:

Menjelang akhir Ramadhan, Anita berniat membeli gamis yang akan dipakai di hari Lebaran. Sebelumnya Anita telah melihat model gamis di Toko Rizki dan Toko. Kebetulan gamis yang diinginkan oleh Anita dijual di dua toko tersebut dengan harga yang sama yaitu Rp 275.000,00. Toko Rizki memberikan diskon 30\%, sementara Toko Rejeki memberikan diskon 20\% $+12 \%$ atas gamis tersebut. Bantulah Anita untuk membandingkan harga jual di kedua toko sehingga Anita dapat menentukan ke toko mana dia akan belanja!

Adapun jawaban siswa pada persoalan tersebut sebagai berikut: 


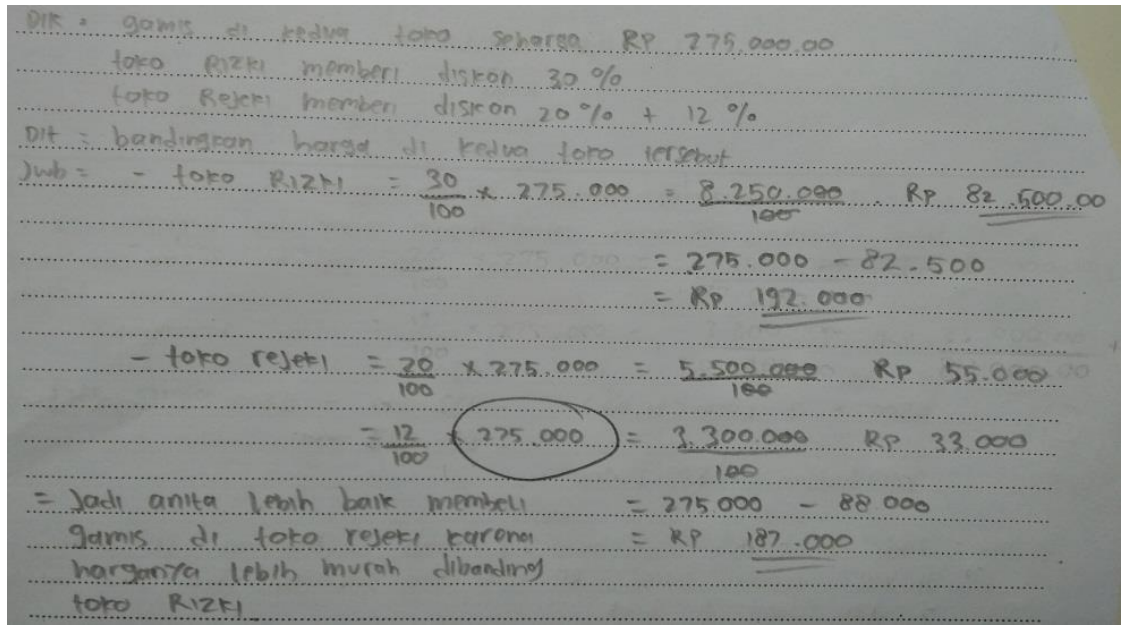

Gambar 1. Jawaban siswa dengan kemampuan tinggi

Gambar 1 merupakan jawaban siswa berkemampuan tinggi pada soal C5. Terlihat bahwa siswa telah mampu memahami masalah dengan menuliskan atau mendata semua informasi yang terdapat pada soal menggunakan bahasa sendiri tanpa terpengaruh pada bahasa soal. Kemudian siswa mampu membuat strategi penyelesaian dan menjalankan strategi tersebut dengan tepat disaat siswa mengitung diskon $30 \%$, siswa mengerjakan soal dengan sistematis dan melakukan perhitungan dengan tepat. Artinya siswa telah memahami konsep diskon tunggal dengan benar, namun siswa dalam menentukan strategi dan menjalankan rencana terhadap perhitungan diskon pertambahan $(20 \%+12 \%)$ kurang tepat. Dalam hal ini siswa gagal dalam memahami konsep diskon pertambahan. Siswa dalam menghitung diskon $+12 \%$ sama halnya dengan diskon tunggal $20 \%$ yang dikalikan terhadap harga pembelian. Hal tersebut jelas kurang tepat, karena diskon $+12 \%$ dikalikan terhadap harga pembelian yang telah dikenakan diskon 20\%. Hal tersebut sejalan dengan (Astutik \& Nuriyatin, 2016) bahwa kesulitan siswa dalam memahami soal aritmatika terletak pada kesalahan konsep.

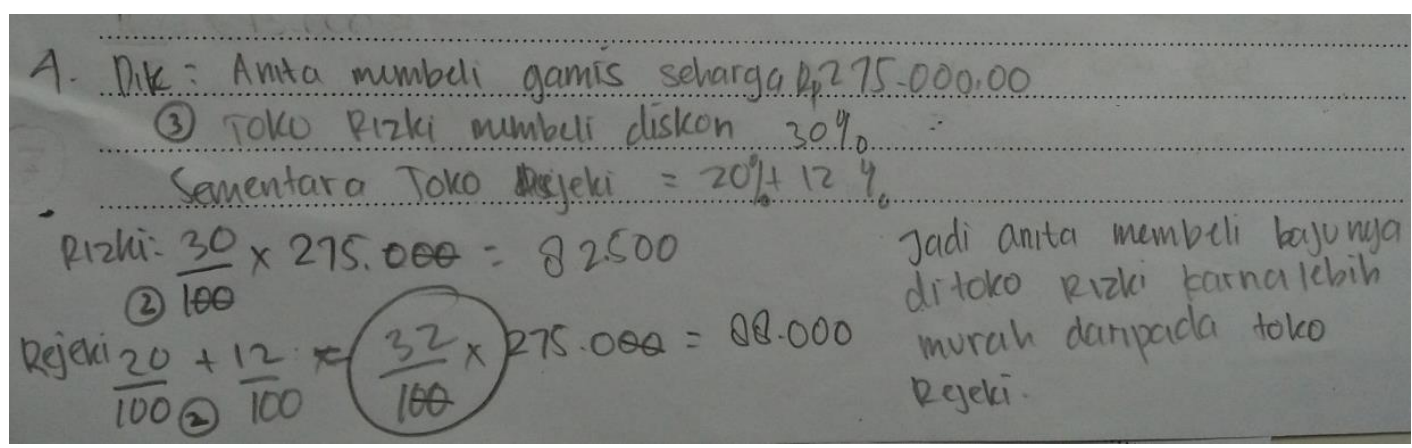

Gambar 2. Jawaban siswa dengan kemampuan sedang

Berdasarkan gambar 2 yang merupakan jawaban siswa berkemampuan sedang terlihat siswa telah memahami masalah karena telah menuliskan informasi yang terdapat pada soal menggunakan bahasa sendiri. Siswa juga mampu menghitung diskon tunggal sebesar 30\% dengan tepat, namun gagal dalam memahami konsep dari diskon penambahan $(20 \%+12 \%)$. Dalam hal ini siswa melakukan kesalahan prinsip, siswa langsung melakukan penambahan untuk menghitung diskon tersebut. Kesalahan prinsip 
juga merupakan salah satu kesalahan yang dilakukan oleh siswa dalam menyelesaikan soal aritmatika sosial (Astutik \& Nuriyatin, 2016). Namun siswa mampu membuat kesimpulan dengan menuliskan kesimpulan berdasarkan perhitungan besarnya diskon tanpa menghitung harga pembelian pada masingmasing diskon yang diberikan.

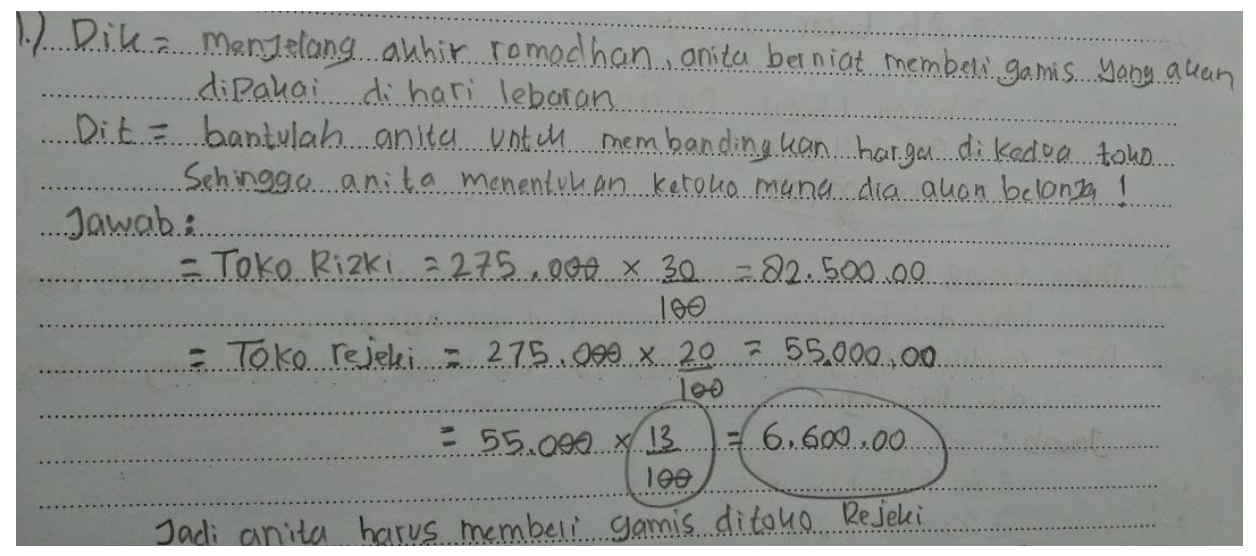

Gambar 3. Jawaban siswa 1 dengan kemampuan rendah

Berdasarkan gambar 3, terlihat bahwa siswa belum mampu memahami masalah. Hal tersebut didasarkan pada tidak data yang ditulis pada jawaban dan hanya menuliskan kalimat yang terdapat pada soal. Akibatnya siswa menuliskan $13 \%$, padahal informasi diskon yang terdapat pada soal yaitu $20 \%+12 \%$. Disamping itu siswa juga kurang tepat dalam melakukan operasi perkalian pada diskon $13 \%$ yaitu dengan menuslikan Rp 6.600,00 seharusnya siswa menuslikan jawaban sebesar Rp 7.150,00. Hal tersebut sejalan dengan pernyataan Astutik \& Nuriyatin (2016) bahwa masih banyak siswa yang kurang memahami prosedur pengoperasian matematika dengan baik.

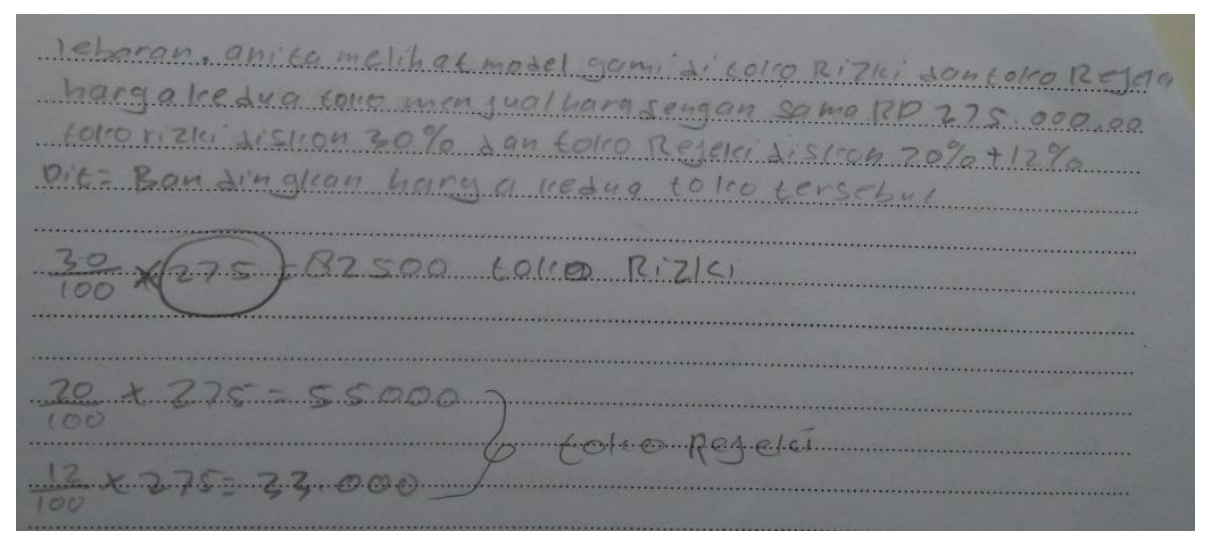

Gambar 4. Jawaban siswa 2 dengan kemampuan rendah

Berdasarkan gambar 4 terlihat bahwa siswa kurang memahami permasalahan, siswa menulis ulang bahasa soal tanpa meringkas kalimat. Artinya siswa tidak menggunakan bahasa sendiri dalam mengumpulkan informasi. Selain itu, siswa juga kurang memperhatikan hal-hal penting yang terdapat pada informasi soal. Terbukti disaat siswa melakukan perhitungan diskon yang dikalikan terhadap harga pembelian dimana siswa hanya menuliskan 275 yang mana harga pembelian seharusnya sebesar Rp 
275.000,00. Hal tersebut jelas merubah pengertian, berbeda antara pengertian ratusan dengan ratusan ribu. Kesalahan tersebut sejalan dengan pernyataan Kurniawan \& Setiawan (2019) bahwa salah satu kesalahan siswa dalam mengerjakan soal berbentuk cerita adalah siswa tidak memperhatikan hal-hal detail dalam sebuah informasi dan berdampak terhadap hasil pengerjaan siswa.

\section{KESIMPULAN}

Berdasarkan hasil analisis data dan pembahasan dapat disimpulkan bahwa kemampuan rata-rata siswa kelas VIII-E SMP Mahardika masih tergolong rendah. Hal tersebut dapat diketahui dari masih banyaknya siswa yang mengalami kesulitan dan kesalahan dalam menyelesaikan soal aritmatika sosial. Adapun bentuk kesalahannya cukup bervariasi, dimulai dari kesalahan dalam memahami konsep materi, kesalahan membuat rumus penyelesaian atau kesalahan prinsip, kesalahan dalam melakukan operasi aljabar, dan beberapa siswa tidak memperhatikan hal-hal detail dalam menyelesaikan soal. Akibatnya siswa tidak dapat menyelesaikan permasalahan dengan tepat dan hasilnya pun kurang memuaskan.

\section{DAFTAR PUSTAKA}

Astutik, Y., \& Nuriyatin, S. (2016). Analisis Kesalahan Siswa dalam Menyelesaikan Soal Cerita Aritmatika Sosial. Jurnal Pendidikan Matematika, 4(2).

Fitiani, N. (2015). Hubungan antara Kemampuan Pemecahan Masalah dengan Self Confidence Siswa SMP yang Menggunakan Pendeketan Pendidikan Matematika Realistik. Jurnal Euclid, 2(2), 341251.

Giani, G., Zulkardi, Z., \& Hiltrimartin, C. (2015). Analisis Tingkat Kognitif Soal-Soal Buku Teks Matematika Kelas VII Berdasarkan Taksonomi Bloom. Jurnal Pendidikan Matematika, 9(2), 78 98.

Irawati, T. N., \& Mahmudah, M. (2018). Pengembangan Instrumen Kemampuan Berpikir Analisis Siswa SMP dalam Menyelesaikan Soal Pemecahan Masalah Matematika. Kadikma, 9(2), 1-11.

Kurniawan, A., \& Setiawan, D. (2019). Analisis Kemampuan Pemecahan Masalah Matematis Siswa SMP Berbantuan Soal Kontekstual pada Materi Bangun Ruang Sisi Datar. JPMI (Jurnal Pembelajaran Matematika Inovatif), 2(5), 271-282.

Nurfauziah, P., \& Fitriani, N. (2019). Gender dan Resiliensi Matematis Siswa SMP dalam Pembelajaran Scientific Berbantuan VBA Excel. Symmetry: Pasundan Journal of Research in Mathematics Learning and Education, 4(1), 28-37.

Paramitha, N., \& Yunianta, T. (2017). Analisis Proses Berpikir Kreatif dalam Memecahkan Masalah Matematika Materi Aritmatika Sosial Siswa SMP Berkemampuan Tinggi. Jurnal Mitra Pendidikan (JMP Online), 1(10), 983-994.

Rahmah, A. N., \& Muharni, L. P. J. (2019). Identifikasi Soal Tipe Higher Order Thinking Skills (HOTS) pada Buku Matematika Materi Persamaan dan Pertidaksamaan Linear Satu Variabel. Edu Math Journal Prodi Pendidikan Matematika, 7(1), 1-8. 
Romika \& Amalia, Y. (2014). Analisis Kemampuan Pemecahan Masalah Matematika Siswa pada Materi Bangun Ruang Sisi Datar dengan Teori Van Hiele. Bina Gogik, 1(2), 17-31.

Ruseffendi. (2006). Pengantar Kepada Membantu Guru Mengembangkan Kompetensinya dalam Pengajaran Matematika untuk Meningkatkan CBSA. Bandung: Tarsito.

Sari, A. M., Susanti, N., \& Rahayu, C. (2018). Analisis Kesalahan Siswa dalam Menyelesaikan Soal Cerita Materi Aritmatika Sosial Kelas VII. JP3M (Jurnal Penelitian Pendidikan dan Pengajaran Matematika), 4(2), 61-68.

Suherman, E. (2003). Strategi Pembelajaran Matematika Kontemporer. Bandung: JICA-Universitas Pendidikan Indonesia (UPI).

Wahyuddin, W. (2017). Analisis Kemampuan Menyelesaikan Soal Cerita Matematika Ditinjau dari Kemampuan Verbal. Beta Jurnal Tadris Matematika, 9(2), 148-160. 